\title{
Monitoring and Evaluating Fiscal Solvency in times of Crisis: Framework for Enhancing Revenue Generating Capacity in Nigeria
}

\author{
Festus Fatai ADEDOYIN ${ }^{1 *}$ Safae LAGHMARI ${ }^{2}$ Mehdi TAZI ${ }^{3}$ Abiodun POPOOLA ${ }^{4}$ \\ 1. Ph.D. Candidate, Faculty of Management, Bournemouth University, U.K. \\ 2. Graduate Research Assistant, Higher Institute of Commercial Studies and Business Administration, \\ Morocco. \\ 3. Administrator, Department of the Prime Minister of Morocco \\ 4. Senior Lecturer, Department of Economics, Ahmadu Bello University, Zaria, Kaduna, Nigeria \\ *E-mail: s5076568@bournemouth.ac.uk
}

\begin{abstract}
This study contributes to existing literature on fundamentals of public finance management efforts by sub-national governments in developing economies. The paper's primary contribution is finding that choice of public policy intervention by a central government requires establishing frameworks that first monitors individual efforts of sub-national government before approval of such interventions are made. It also suggests the application of certain methodologies for performance measurement in public finance section of the government.
\end{abstract}

Keywords: Bailout programme, Internally Generated Revenue, Policy Logic, Logframe.

\section{Introduction}

The fiscal crisis in Nigeria is not unconnected from global happenings in the world today, especially in the increased supply of crude oil to the global oil market, leading to a fall in the global price per barrel of crude oil. In fact, this situation grossly affected the country's revenue with a fall in federal government revenue that results a decline in Monthly Statutory Allocations to State Governments. Therefore, 27 out of 36 states government became unable to pay salary and pension arrears alongside with huge debts and falling internally generated revenue.

The overall goal of this policy is to achieve fiscal solvency of the state, which means that the sources of revenue of the government should be sufficient to meet the demand of recurrent expenditures ${ }^{1}$, and to lower debt. The policy was expected to have two main outcomes; increasing the revenue generating capacity of the states and enhancing the financial management of the state's executives. There is a demand from the National Assembly (Congress) as well as the opposition for efficiency and effectiveness in the use of the bailout fund. The payment of the bailout fund, which was up to, N338billion (US\$1.35billion) was approved by the president on October 2015, and was kept in custody of Deposit Money Banks in Nigeria (Central Bank of Nigeria, 2015). The Debt Management Office (DMO) is responsible for the monitoring and evaluation of this policy, and is expected to champion the progress of the bailout program.

In the same vain, the ministry of budget and national planning currently has no framework to improve the availability, quality and dissemination of government performance information for accountability and policy improvement purposes on the bailout programme. Therefore, we proceed to highlight a framework to support the monitoring, evaluation and reporting of state government performance in the use of bailout funds.

\footnotetext{
${ }^{1}$ Recurrent expenditure here refers to payment of salaries and pension arrears of civil servants.
} 
This paper introduces a scientific and logical monitoring and evaluation (M\&E) framework for the recent fiscal stimulus package a.k.a. bailout programme, embarked upon by the Federal Government of Nigeria (FGN). It builds on the strength of World Bank's ten steps for monitoring and evaluating public policy (Jody Z.K. and Ray C.R.2004), and modifies these recommendations to establish a framework for central government interventions in times of fiscal crisis.

On one hand, the benefits embedded in monitoring is to; provide a continuous assessment of the fiscal solvency of the states; provide the federal government, tax payers, state governor executives, international community, and other stakeholders with timely detailed information on the progress or delay of the use of incentives, enforcements, and media campaign to increase revenue generating capacity of the states; give an oversight of each activity's implementation stage; determine if the increase in the IGR amount of states has been reached so that action can be taken to correct the deficiencies as quickly as possible; and to track the means and strategies (inputs, activities, and outputs in a work plan) used to achieve given outcome.

Similarly, the purpose of evaluation is to; find out whether key activities set out to boost the internally generated revenue of the states has achieved their desired results, to what extent, and what the most highlighted success factors are, what the challenges and barriers were in terms of policy implications - at the state and national level; provide recommendations and lessons to the project managers and implementation teams that have worked on the projects and for the ones that will implement and work on similar projects; and serve as a means to report to the federal government about the policy.

\section{Policy Logic}

The policy logic is a model that captures the theoretical framework of a monitoring and evaluation study. It is a tool that aids efficiency, effectiveness, accountability, and transparency. The policy logic is designed based on efforts of the government in achieving adequate service provisions. It is derived from established inputs \& outputs, which tell little about the effectiveness (outcomes and impacts) of a policy or intervention. Thus, in order to ensure the development of sufficient understanding of what policy works, what does not, and why, the policy logic is utilized.

As figure 1 shows, policy logic captures the flow of interactions amongst alternative policy options and follows a process, which collects data on how well the selected project option behaves. In achieving fiscal solvency of states, activities that'd boost income for the government could be followed and/or a tightening of spending i.e. ensuring stricter form of fiscal management could be adopted.

The efforts put together in subsequent section of this paper is in support of a policy option that'd enhance revenue-generating capacity for sub-national levels of government, applicable especially in developing countries with proven leaks in central fiscal purse. 
[Goal] - Achieving Fiscal Solvency by states government

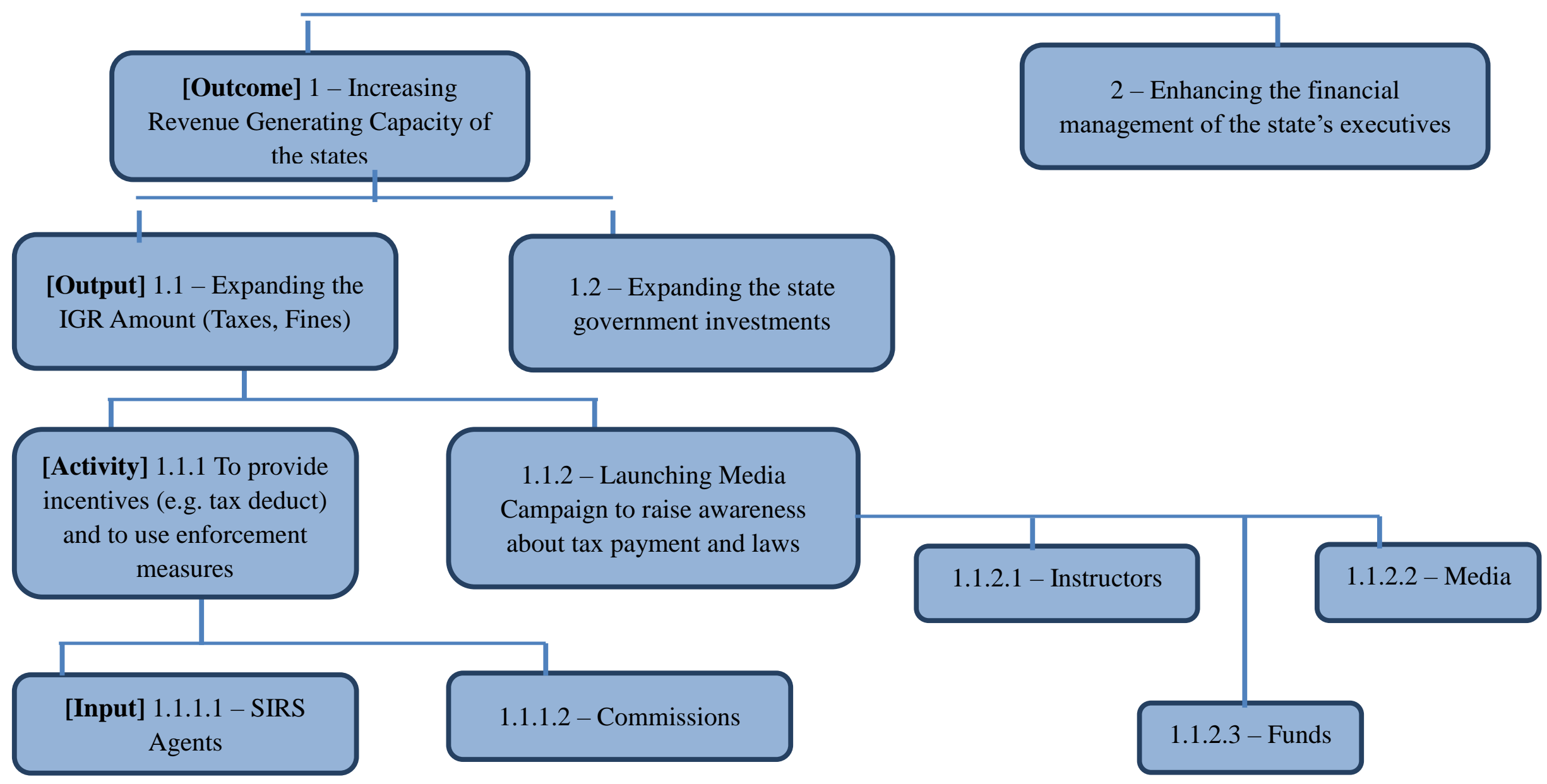

Source: Author's compilation 


\section{Monitoring Plan}

In order to have a monitoring plan, it is important to highlight; the policy problem; the objective of the plan; a logframe that is captured in the policy logic; as well as a proposal for expected results from the monitoring processes. The statement of research problem for this paper is presented in this section. It is captured by figure 2, which shows the origin of the policy problem, and a flow of its enlarged effects on the Nigeria economy during the oil crisis in 2014.

Figure 2: Problem Tree to develop a Hierarchy of Objectives for monitoring the policy [Source: Author's compilation]

Below is the problem tree that describes the sources of the core problem leading to the bailout policy its causes and effects.

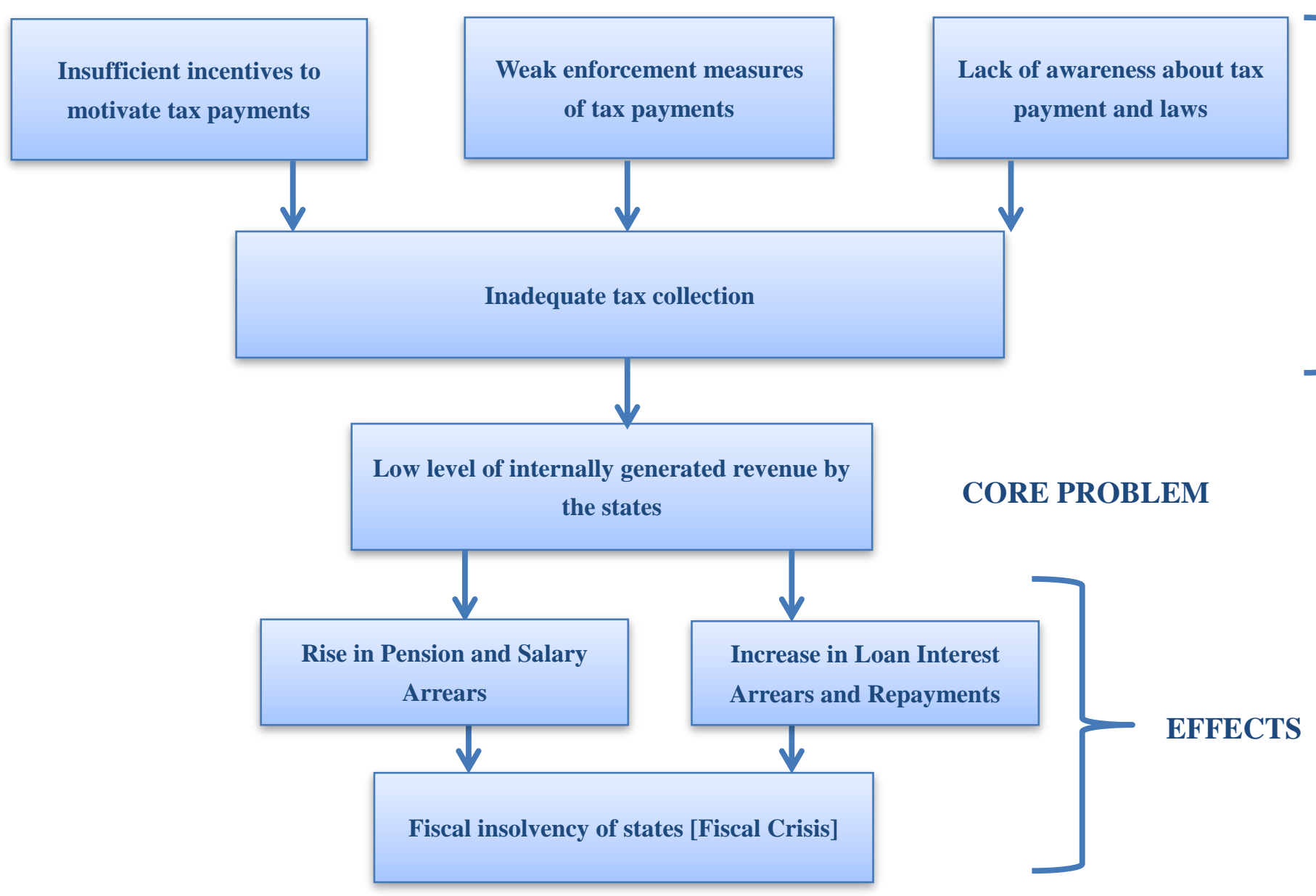




\section{Figure 3: Objective Tree [Source: Author's Compilation]}

In order to compile the Logframe, the diagram below shows the Objective tree. This is prepared with insights from the Problem tree mentioned above with similar structure. Our aim is to highlight the logical linkage between the means used to achieve the ends i.e. relationships among goal, outcomes, outputs, activities and inputs.

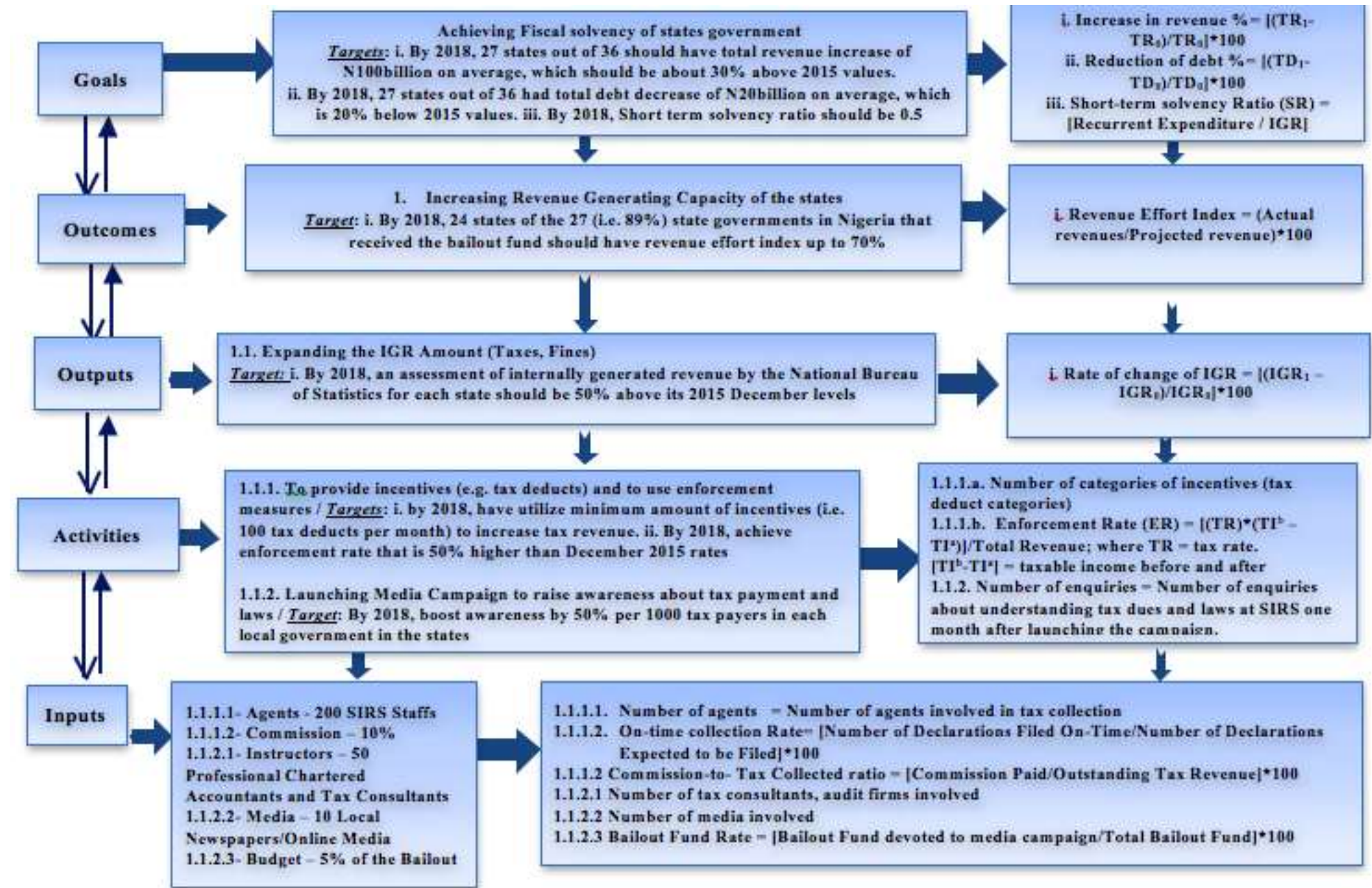




\section{Table 1: Logframe}

This section presents the logical framework to aid our analysis of the current situation of the fiscal management of the bailout funds as well as the means to achieve set objectives and meet up with expected outcomes. Also, this section highlights certain risks that may hamper achievement of set objectives, as well as assumptions about all stakeholders involved in the bailout policy. These risks are factored into the monitoring and evaluation process so as to reach the expected outcomes of the bailout policy.

\begin{tabular}{|c|c|c|c|}
\hline Hierarchy of objectives & Key Performance Indicators & Means of Verification & Assumptions and Risks \\
\hline $\begin{array}{l}\text { Goal: Achieving Fiscal solvency of states government } \\
\text { means that the sources of revenue of the government } \\
\text { should be sufficient to meet the demand of recurrent } \\
\text { expenditures }{ }^{2} \text {, and to lower debts. }\end{array}$ & $\begin{array}{l}\text { i. Increase in revenue } \%=[(\text { TR } 1- \\
\text { TR0)/TR0 }]^{*} 100 \\
\text { ii. Reduction of debt } \%=[(\mathrm{TD} 1- \\
\text { TD0)/TD0 }{ }^{*} 100 \\
\mathrm{TR}=\text { Total Revenue } \\
\mathrm{TD}=\text { Total Debt } \\
\text { iii. Short-term Solvency Ratio = } \\
\text { [Recurrent Expenditure / IGR }]\end{array}$ & $\begin{array}{l}\text { Annual Statistical } \\
\text { Bulletin released by: } \\
\text { i. Office of State's } \\
\text { Commissioner of } \\
\text { Finance } \\
\text { ii. Office of State } \\
\text { Auditor General } \\
\text { iii.. Debt Management } \\
\text { Office annual reports }\end{array}$ & $\begin{array}{l}\text { Assumptions: Funding of Federal Government's } \\
\text { National Development agendas will not } \\
\text { obstruct individual states' fiscal performance. } \\
\text { Potential risks: State Governors and other state } \\
\text { executives may not be committed to the bailout } \\
\text { policy and/or may not respond timely enough to } \\
\text { possible shocks to the Nigerian economy }\end{array}$ \\
\hline $\begin{array}{l}\text { Outcome: Increasing Revenue Generating Capacity of } \\
\text { the states means increasing the total revenue that a } \\
\text { state would have raised if it were to apply a uniform } \\
\text { set of taxes, fines and project generating revenue } \\
\text { which reflects current economic conditions across the } \\
\text { states. Also, in comparison to the debt stock, each } \\
\text { state should be able to expand its revenue through } \\
\text { adequate tax compliance, fines and. Project } \\
\text { generating revenue. }\end{array}$ & $\begin{array}{l}\text { i. Revenue Effort Index }=\text { (Actual } \\
\text { revenues/Projected revenue) } * 100\end{array}$ & $\begin{array}{l}\text { i. Annual Report of } \\
\text { National Bureau of } \\
\text { Statistics } \\
\text { ii. Debt Management } \\
\text { Office annual reports }\end{array}$ & $\begin{array}{l}\text { Assumptions: Macroeconomic conditions will } \\
\text { remain stable and debts, revenue, and } \\
\text { expenditure interpolations will yield sustainable } \\
\text { index } \\
\text { Potential risks: Bailout fund interests may } \\
\text { compound as states make efforts to cover only } \\
\text { outstanding debts and repayments. }\end{array}$ \\
\hline $\begin{array}{l}\text { Output: Expanding the IGR Amount (Taxes, Fines) } \\
\text { means collecting taxes more resourcefully through } \\
\text { incentives and launching media campaigns to make }\end{array}$ & i. Rate of change in IGR & $\begin{array}{l}\text { i. Annual reports of } \\
\text { State Inland Revenue } \\
\text { Service (SIRS) }\end{array}$ & $\begin{array}{l}\text { Assumptions: State has potential (economic } \\
\text { activities - companies and individuals) to } \\
\text { generate revenue from. }\end{array}$ \\
\hline
\end{tabular}

\footnotetext{
${ }^{2}$ Recurrent expenditure here refers to payment of salaries and pension arrears of civil servants.
} 


\begin{tabular}{|c|c|c|c|}
\hline Hierarchy of objectives & Key Performance Indicators & Means of Verification & Assumptions and Risks \\
\hline tax payers comply with tax laws & $\mathrm{Ro} \Delta=\left[\left(\mathrm{IGR}_{1}-\mathrm{IGR}_{0}\right) / \mathrm{IGR}_{0}\right] * 100$ & $\begin{array}{l}\text { ii. Annual reports of } \\
\text { Office of State Auditor } \\
\text { General }\end{array}$ & $\begin{array}{l}\text { Potential risks: Recurrent expenditure may } \\
\text { continue to increase without IGR been able to } \\
\text { meet up with expectations }\end{array}$ \\
\hline $\begin{array}{l}\text { Activity: } 1.1 .1 \text {. To provide incentives (e.g. tax deduct) } \\
\text { and to use enforcement measures: Motivating or } \\
\text { enforcing tax payers to commit to payment of taxes } \\
\text { through tax rebates and other incentives in order to } \\
\text { increase the amount of tax collection. }\end{array}$ & $\begin{array}{l}\text { Number of incentives } \\
\text { Enforcement Rate } \\
\mathrm{ER}=\left[(\mathrm{TR}) *\left(\mathrm{TI}^{\mathrm{b}}-\mathrm{TI}^{\mathrm{a}}\right)\right] / \text { Total Revenue; } \\
\text { where } \mathrm{TR}=\text { tax rate. } \\
{\left[\mathrm{TI}^{\mathrm{b}}-\mathrm{TI}^{\mathrm{a}}\right]=\text { taxable income before and }} \\
\text { after }\end{array}$ & $\begin{array}{l}\text { Survey reports from } \\
\text { Enforcement Office of } \\
\text { the SIRS }\end{array}$ & $\begin{array}{l}\text { Assumptions: Tax payers (Companies and } \\
\text { Individuals) will comply with tax payments. } \\
\text { Potential risks: Tax incentives and enforcement } \\
\text { are not efficient to make tax payers comply }\end{array}$ \\
\hline $\begin{array}{l}\text { Activity: } 1.1 .2 \text {. Launching Media Campaign to raise } \\
\text { awareness about tax payment and laws: Utilize } \\
\text { instructors to clarify tax laws and need to comply with } \\
\text { tax payment. }\end{array}$ & $\begin{array}{l}\text { Number of enquiries about understanding } \\
\text { tax dues and laws at SIRS one month } \\
\text { after launching the campaign }\end{array}$ & $\begin{array}{l}\text { Enquiry log from } \\
\text { Enforcement Office of } \\
\text { the SIRS }\end{array}$ & $\begin{array}{l}\text { Assumptions: Tax payers will have access to the } \\
\text { media campaign. } \\
\text { Potential risks: Tax laws remain unclear to tax } \\
\text { payers }\end{array}$ \\
\hline $\begin{array}{l}\text { Inputs: } \\
\text { 1.1.1.1- Agents - } 200 \text { SIRS Staffs } \\
\text { 1.1.1.2- Commission }-10 \% \\
\text { 1.1.2.1- Instructors - } 50 \text { Professional Chartered } \\
\text { Accountants and Tax Consultants } \\
\text { 1.1.2.2- Media - } 10 \text { Local Newspapers/Online Media } \\
\text { 1.1.2.3- Budget }-5 \% \text { of the Bailout }\end{array}$ & $\begin{array}{l}\text { 1.1.1.1.Number of agents } \\
\text { 1.1.1.2.On-time collection Rate } \\
\text { 1.1.1.3. Commission-to- Tax Collected } \\
\text { ratio } \\
\text { 1.1.2.1.Number of tax consultants, audit } \\
\text { firms involved } \\
\text { 1.1.2.2.Number of media involved } \\
\text { 1.1.2.3.Bailout Fund Rate }\end{array}$ & $\begin{array}{l}\text { Reports from } \\
\text { Enforcement Office of } \\
\text { the SIRS }\end{array}$ & $\begin{array}{l}\text { Assumptions: Agents will perform to full } \\
\text { capacity, commissions will be paid timely and } \\
\text { bailout funds meant for media and instructors } \\
\text { will be paid accordingly. } \\
\text { Potential Risk: Possible Misuse or } \\
\text { mismanagement of funds i.e. corruption }\end{array}$ \\
\hline
\end{tabular}

Source: Author's compilation

\section{Table 2: Results Monitoring Table}

This section presents the data collection and management from related agencies responsible. In addition, this section presents the target years (2015 - 2018$)$, in 
order to track the progress of indicators used to measure goals, outcomes, outputs, and activities. This result monitoring plan will aid our linkage of set baseline data with the results targets of the bailout policy for each key performance indicator in use.

The data should be collected before the M\&E so establish the baseline data, during the monitoring, and also after the monitoring so as to enable evaluation study.

\begin{tabular}{|c|c|c|c|c|c|c|c|c|}
\hline \multirow[b]{2}{*}{ Indicator } & \multirow[b]{2}{*}{ Baseline } & \multicolumn{4}{|c|}{ Target Years } & \multicolumn{3}{|c|}{ Data Collection and Reporting } \\
\hline & & $\begin{array}{l}Y_{0} \\
2015\end{array}$ & $\begin{array}{l}Y_{1} \\
2016\end{array}$ & $\begin{array}{l}Y_{2} \\
2017\end{array}$ & $\begin{array}{l}Y_{3} \\
2018\end{array}$ & $\begin{array}{l}\text { Frequency } \\
\text { and } \\
\text { reports }\end{array}$ & $\begin{array}{l}\text { Data } \\
\text { collection } \\
\text { Instruments }\end{array}$ & $\begin{array}{l}\text { Responsibility } \\
\text { for Data } \\
\text { Collection }\end{array}$ \\
\hline $\begin{array}{l}\text { Goal: i. Increase in } \\
\text { revenue } \%=\left[\left(\mathrm{TR}_{1}-\right.\right. \\
\left.\left.\mathrm{TR}_{0}\right) / \mathrm{TR}_{0}\right]^{*} 100 \\
\text { ii. Reduction of debt } \%= \\
{\left[\left(\mathrm{TD}_{1}-\mathrm{TD}_{0}\right) / \mathrm{TD}_{0}\right]^{*} 100} \\
\mathrm{TR}=\text { Total Revenue } \\
\mathrm{TD}=\text { Total Debt } \\
\text { iii. Short-term Solvency Ratio } \\
=[\text { Recurrent Expenditure / } \\
\text { IGR] }\end{array}$ & $\begin{array}{l}\text { i. In } 2015,27 \text { states out of } 36 \text { had } \\
\text { total revenue decrease of } \\
\text { N65billion on average, which is } \\
35 \% \text { below previous year values. } \\
\text { ii. In } 2015,27 \text { states out of } 36 \text { had } \\
\text { total debt increase of N } 50 \text { billion } \\
\text { on average, which is } 30 \% \text { below } \\
\text { previous year values. } \\
\text { iii. In } 2015 \text {, Short term solvency } \\
\text { ratio was } 2\end{array}$ & $\begin{array}{l}-\mathrm{N} 65 \mathrm{bn} \\
(-35 \%) \\
\\
\text { N50bn, } \\
(+30 \%)\end{array}$ & $\begin{array}{l}\text { N20bn } \\
(+5 \%)\end{array}$ & $\begin{array}{l}\text { N70bn, } \\
(+15 \%)\end{array}$ & $\begin{array}{l}\text { N100bn, } \\
(+30 \%)\end{array}$ & $\begin{array}{l}\text { Data } \\
\text { Collection: } \\
\text { Monthly } \\
\text { Data } \\
\text { Reporting: } \\
\text { Annually } \\
\\
\text { Data } \\
\text { Reporting: } \\
\text { Annually }\end{array}$ & $\begin{array}{l}\frac{\text { Nigeria's }}{\text { Data }} \\
\underline{\text { Administrati }} \\
\underline{\text { ve System }}\end{array}$ & $\begin{array}{l}\text { i. Office of State's } \\
\text { Commissioner of } \\
\text { Finance } \\
\text { ii. Office of State } \\
\text { Auditor General } \\
\text { iii. Debt } \\
\text { Management } \\
\text { Office }\end{array}$ \\
\hline $\begin{array}{l}\text { 1. Outcome: } \\
\text { i. Revenue Effort Index = } \\
(\text { Actual revenues/Projected } \\
\text { revenue } * 100\end{array}$ & $\begin{array}{l}\text { i. As at December } 2015,27 \text { states } \\
\text { out of } 36 \text { (i.e. } 75 \% \text { ) state } \\
\text { governments in Nigeria that } \\
\text { received bailout fund totaling } \\
\text { N338billion (US } \$ 1.35 \text { billion) had } \\
\text { revenue effort index below } 30 \%\end{array}$ & $30 \%$ & $40 \%$ & $55 \%$ & $70 \%$ & $\begin{array}{l}\text { Data } \\
\text { Collection: } \\
\text { Monthly }\end{array}$ & $\begin{array}{l}\frac{\text { Nigeria's }}{\text { Data }} \\
\underline{\text { Administrati }} \\
\underline{\text { ve System }} \\
\text { Annual } \\
\text { reports }\end{array}$ & $\begin{array}{l}\text { i. National Bureau } \\
\text { of Statistics } \\
\text { ii. Debt } \\
\text { Management } \\
\text { Office }\end{array}$ \\
\hline
\end{tabular}




\begin{tabular}{|c|c|c|c|c|c|c|c|c|}
\hline & & \multicolumn{4}{|c|}{ Target Years } & \multicolumn{3}{|c|}{ Data Collection and Reporting } \\
\hline Indicator & Baseline & $\mid \begin{array}{l}Y_{0} \\
2015\end{array}$ & $\begin{array}{l}Y_{1} \\
2016\end{array}$ & $\begin{array}{l}Y_{2} \\
2017\end{array}$ & $\begin{array}{l}Y_{3} \\
2018\end{array}$ & $\begin{array}{l}\text { Frequency } \\
\text { and } \\
\text { reports }\end{array}$ & $\begin{array}{l}\text { Data } \\
\text { collection } \\
\text { Instruments }\end{array}$ & $\begin{array}{l}\text { Responsibility } \\
\text { for Data } \\
\text { Collection }\end{array}$ \\
\hline $\begin{array}{l}\text { 1.1. } \frac{\text { Output: }}{\mathrm{Ro} \Delta}=\quad\left[\left(\mathrm{IGR}_{1}-\right.\right. \\
\text { i. } \quad- \\
\left.\left.\mathrm{IGR}_{0}\right) / \mathrm{IGR}_{0}\right]^{* 100}\end{array}$ & $\begin{array}{l}\text { i. In } 2015 \text {, states affected in the } \\
\text { fiscal crisis had IGR falling at an } \\
\text { estimate of } 10 \% \text { below previous } \\
\text { year values. }\end{array}$ & $10 \%$ & $20 \%$ & $35 \%$ & $50 \%$ & $\begin{array}{l}\text { Data } \\
\text { Collection: } \\
\text { Monthly }\end{array}$ & $\begin{array}{l}\frac{\text { Nigeria's }}{\text { Data }} \\
\frac{\text { Administrati }}{\text { ve System }} \\
\begin{array}{l}\text { Quarterly } \\
\text { reports }\end{array}\end{array}$ & $\begin{array}{l}\text { i. State Inland } \\
\text { Revenue Service } \\
\text { (SIRS) } \\
\text { ii. Office of State } \\
\text { Auditor General }\end{array}$ \\
\hline $\begin{array}{l}\text { 1.1.1. Activity } \\
\text { i. Number of incentives } \\
\text { ii. ER = [(TR)*(TI }{ }^{\mathrm{b}}- \\
\left.\left.\mathrm{TI}^{\mathrm{a}}\right)\right] / \text { Total Revenue; where TR } \\
=\text { tax rate. } \\
{\left[\mathrm{TI}^{\mathrm{b}}-\mathrm{TI}^{\mathrm{a}}\right]=\text { taxable income }} \\
\text { before and after } \\
\text { 1.1.2. Activity } \\
\text { Number of enquiries= Number } \\
\text { of enquiries about } \\
\text { understanding tax dues and } \\
\text { laws at SIRS one month after } \\
\text { launching the campaign. }\end{array}$ & $\begin{array}{l}\text { In } 2015 \text {, enforcement rate was } \\
15 \% \text {. } \\
\text { - }\end{array}$ & $15 \%$ & $\begin{array}{l}50 \text { tax } \\
\text { deducts/ } \\
\text { month } \\
35 \% \\
\\
50 \% \\
\text { higher/ } \\
1000 \text { tax } \\
\text { payers }\end{array}$ & $\begin{array}{l}80 \text { tax } \\
\text { deducts/ } \\
\text { month } \\
55 \% \\
\\
50 \% \\
\text { higher/ } \\
1000 \text { tax } \\
\text { payers }\end{array}$ & $\begin{array}{l}100 \text { tax } \\
\text { deducts/ } \\
\text { month } \\
75 \% \\
\\
50 \% \\
\text { higher/ } \\
1000 \text { tax } \\
\text { payers }\end{array}$ & $\begin{array}{l}\text { Data } \\
\text { Collection: } \\
\text { Monthly } \\
\text { Data } \\
\text { Reporting: } \\
\text { Quarterly } \\
\text { Data } \\
\text { Collection } \\
\text { and } \\
\text { Reporting: } \\
\text { Monthly }\end{array}$ & $\begin{array}{l}\text { Survey } \\
\text { reports }\end{array}$ & $\begin{array}{l}\text { Enforcement } \\
\text { Office of the } \\
\text { SIRS }\end{array}$ \\
\hline
\end{tabular}

Source: Author's compilation

\footnotetext{
${ }^{3}$ Activities of incentive and campaign response are new therefore there are no baseline data.
} 


\section{Evaluation Plan}

\section{i. Key Evaluation Questions based on the hierarchy of objectives and KPIs}

This evaluation focuses on the following evaluation questions:

\section{Relevance}

1.1. Did states government revenue generating capacity improve?

1.1.1. To what extent?

1.1.2. Is the improvement in revenue generating capacity due to the activities? Or due to other factors?

1.1.3 Does the Revenue Effort Index assess the improvement of the state revenue generated?

Method: i. Before-and-After Comparison

ii. Panel Regression (For causality)

\section{Effectiveness}

2.1. How effective were the activities used?

2.1.1. Were incentives and enforcements available?

2.1.2. If yes, were the agents effective to make tax payers comply?

2.1.3. How (do you think) the number of enquiries could be improved?

2.1.4. If incentives and enforcement were not available, which enforcements and campaign strategies were not available?

2.1.5. What were the challenges encountered during the implementation of the activities?

Methodology: i. Survey Design (Two sets of Questionnaire design for Agents and Tax payers after the policy)

\section{Efficiency}

3.1 Does this project use the resources in the economical manner to achieve its objectives?

3.1.1 Are the available resources adequate to meet the revenue generating capacity expansion needs?
3.1.2. To what extent did the use of instructors and trainings on tax laws efficient in terms of influencing tax payers as compared to the result achieved?

3.1.3. Was the media campaign effective to make tax payers comply more?

Method: Cost benefit analysis

\section{Impact}

4.1. Is this policy consistent with the overall goal of fiscal solvency?

4.1.1. How did providing incentives (e.g. tax deduct) work in conjunction with other activities (enforcement; media) to improve internally generated revenue?

4.1.2. To what extent does increasing revenue generating capacity of the states align with overall reduction of debts and increasing revenue?

Method $i$. Before-after comparison

\section{Sustainability}

5.1. Is the impact of this policy likely to be sustainable?

5.1.1. What lessons can we draw to ensure the success of future implementation of the policy?

5.1.2. Did revenue generating capacity of the state government return to falling levels or continued to improve?

5.1.3. Are the results achieved sustained, if not what were the challenges faced?

5.1.4 How the capacity building can sustain the M\&E system?

5.1.5 What are the indicators that assess the effectiveness of capacity building in sustaining M\&E system?

Method Before-after comparison

Key evaluation questions on the causal effect of increase in revenue generating capacity of the states on fiscal solvency

What is the effect of the interventions: media campaign, enforcement measures and incentives on change in revenue in the 27 states? 


\section{ii. Specific Objectives}

"The final report of the evaluation is to be incorporated as a major policy requirement for state government to access Federal government fiscal support in future. The fiscal solvency plan is needed to address aching causes of rising fiscal insolvency of states in Nigeria: insufficient incentives to motivate tax payments, weak enforcement measures of tax payments and lack of awareness about tax payment and laws. In particular, the evaluation aims to find out the impact (causality) of expanding States' IGR amount (majorly taxes and fines) to increasing revenue generating capacity of the states. This would be a very useful policy implication to share with other SSA or Latin American countries with low fiscal solvency of sub-national level governments"

\section{iii. Methodology}

\section{Survey Design}

The population in this evaluation study is all the taxpayers in each state. Since the sample is the representative of the whole population, two sets of questionnaire will be distributed randomly across the local governments. Thus, the study will use the simple random sampling method. Since each state has above 20 local governments, a total of 1000 questionnaires will be distributed to respondents randomly to give all samples equal chance of representation. Also, since agents are SIRS staffs, they will fill in questionnaires as part of their evaluation.

Also, in this evaluation study, the research survey questionnaires will be distributed to 1000 respondents that have knowledge about the policy and are affected directly by this policy. The time for the survey will be during the evaluation.

\section{Cost-Benefit Analysis (CBA)}

The CBA analysis is financial in nature. It will involve a list and assessment of alternative policies or strategies, identify all the stakeholders involved, and select appropriate measurement for the cost/benefit elements. Also, the CBA analysis will predict outcome of cost and benefits over relevant the four years of the policy. These costs and benefits will be converted into a common currency, and an appropriate discount rate will be applied.

For analysis of results of the CBA findings, the net present value (NPV) of the policy will be compared with alternatives, and a sensitivity analysis will be performed.

\section{Before -and-after comparison}

For questions focusing on change before and after the implementation of the policy, we will use descriptive statistics to show charts and graphs that plots past and current revenue trend analysis. This will capture how efficient, effective and relevant the policy interventions contribute to achieving fiscal solvency of states before, during and after the policy implementation. 
Figure 4: Trend to show the behavior of the policy

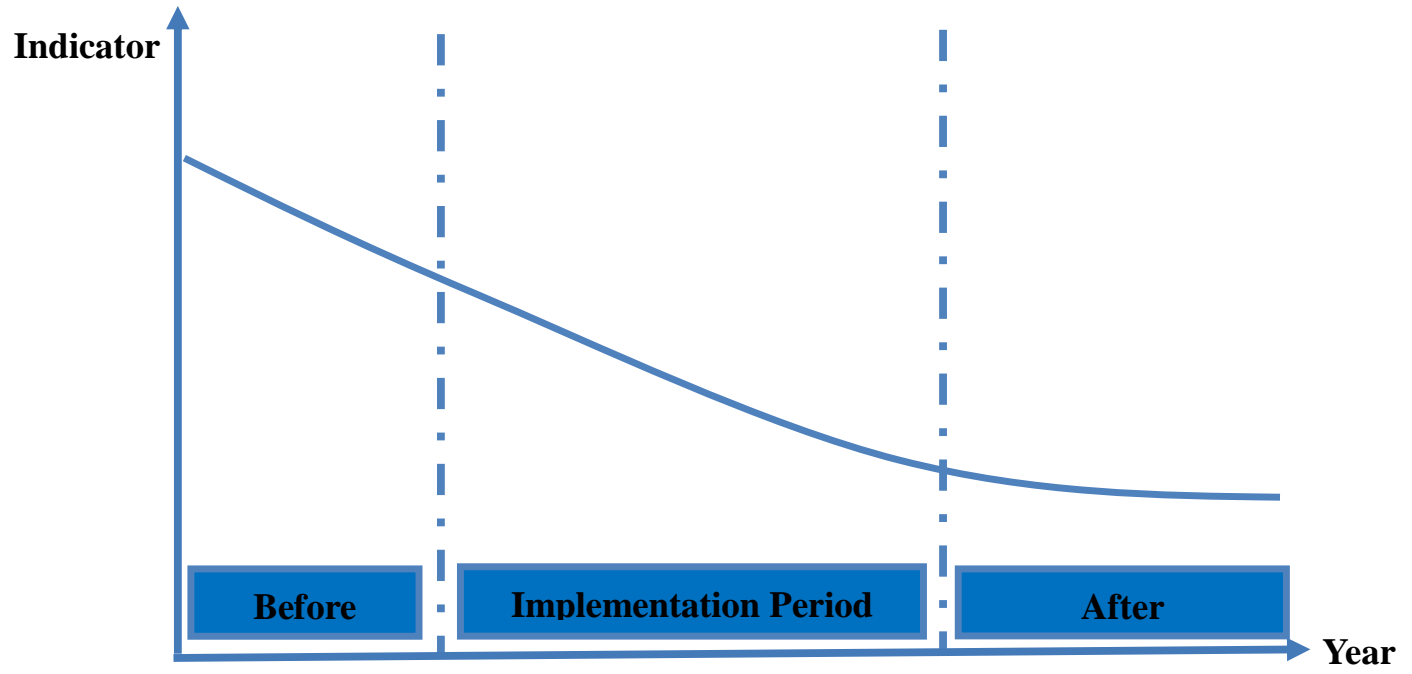

Source: Author's compilation

\section{Panel Regression (For causality)}

The evaluation plan suggests the use of causal inference models with longitudinal data and static panel data estimators. Longitudinal/panel data is a distinct case of pooled time-series and cross-section in which the same cross-section such as entities (e.g. states, companies, individuals, and countries) is measured over time. In this evaluation plan, the cross-section includes a sample of 27 states, and yearly observations of a number of variables will be collected.

In using panel data, we adjust for individual heterogeneity; get more informative data, as well as variability, efficiency and good degrees of freedom. Also, we benefit from less collinear relationship among regressors. This leads to the building and testing of more complex behavioral models, and longitudinal unit root tests that possess standard asymptotic distributions. A problem to overcome with panel data is the homogeneity assumption, and though formal tests exist that would evaluate its validity, there is a possibility of cross-sectional dependence that would complicate the analysis. As such, certain methods and tests need balanced panels and cross-state data consistency.

\section{Pre-Estimation}

The results should present the summary statistics of the indicators (variables), scatter plot of these indicators, and a correlation matrix. The study proceed to test for heteroskedasticity, and to decide on whether to use the fixed effects of random effects estimation techniques, after conducting the Hausman specification test.

\section{Estimation}

The framework should make use of Ordinary Least Squares (OLS) with pooled data, and will proceed to apply either Fixed Effects (FE) or Random Effects (RE) estimation methods depending on Hausman specification test.

$Y_{i t}=\beta_{i}+\beta_{1} \mathrm{X}_{1 i t}+\beta_{2} \mathrm{X}_{2 i t}+\beta_{3} \mathrm{X}_{3 i t}+\beta_{4} \mathrm{X}_{4 i t}+\gamma_{0} \mathrm{Z}_{i}+\varepsilon_{i t}$

where the dependent variables $\mathrm{Y}=$ Change in Revenue where it $=$ state $\mathrm{i}$ in time $\mathrm{t}$

$X_{1}=$ Number of inquiries; $X_{2}=$ Enforcement rate; $X_{3}=$ Number of incentives;

$\mathrm{Z}=$ Control Variables; $\square_{i t}$ stands for the error term.

To start with, a simple strategy is to estimate the model in equation (1) and (2) using OLS regression. However, there are problems with this strategy. Two of these problems include; endogeneity problems which may be due to the capturing of reverse causality issue or the effect of some of the omitted variables (e.g., geographical characteristics, culture and so on); and the possibility of measurement error of our variables of interest. This is because such errors 
will load into other variables.

If not corrected, these two problems will yield OLS estimates that do not correspond to the causal effect of increase in revenue generating capacity of the states on fiscal solvency. Thus, upward or downward biases are possible.

The next strategy is therefore to use either the fixed effects or random effects panel data model. This model is reasonably effective to figure out the causes of changes within a sample. Thus, the fixed or random effects model controls for all time-invariant differences between the 27 states government in Nigeria, so that the estimated coefficients are unbiased because of omitted time-invariant characteristics such as ability to attract foreign investor to a state, fiscal behaviour of state executives, state's budget structure, amongst others.

\section{The utilization of the evaluation results:}

The findings of the evaluation study:

- Will be reported to the congress to justify the bailout allocated to the states.

- Will be available for the citizens (as tax payers) through the DMO website and the media (television, newspapers, social media), to allow them assessing the states' utilization of public money.

- Will strengthen the accountability of the federal state as a whole as well as the states executives (governors, public officials).

- Will serve to promote budget advocacy and transparency in order to build public trust.

- Will be shared among all the states, relevant ministries and all the other stakeholders to promote the organizational culture in terms of adopting the monitoring and evaluation as instrument for effectiveness and efficiency.

\section{Capacity Building For Monitoring and Evaluation}

Three main elements are important for capacity building: technical capacity; managerial capacity; infra-physical for data collecting and management. Thus, to sustain the M\&E results of the bailout policy, a series of capacity strengthening workshops and lectures done by M\&E experts and trainers from national and international universities and private consulting firms, will be given to the public officials working at the level of each states that were part of the bailout policy, in order to equip them with the necessary skills and tools in terms of using the monitoring system as well as the evaluation plan to enhance their work performance and motivate them during the implementation of the current policy as well as for future projects.

A workshop is designed to be conducted over a 5 day period. It will use educational materials such as M\&E's guide together with the PowerPoint files and Workshop Handouts documents. This training will be provided every two years in order to keep the public officials updated with the latest best practices and technologies used for M\&E but also motivated to achieve their assigned tasks. Manuals and guidebooks will be distributed at the level of all ministries and government agencies to serve as a reference for M\&E systems implementation, and to provide an exhaustive list of the best practices and lesson learned from previous M\&E projects. 
Table 3: A model recommendation for Nigeria's National M\&E Capacity Building Plan:

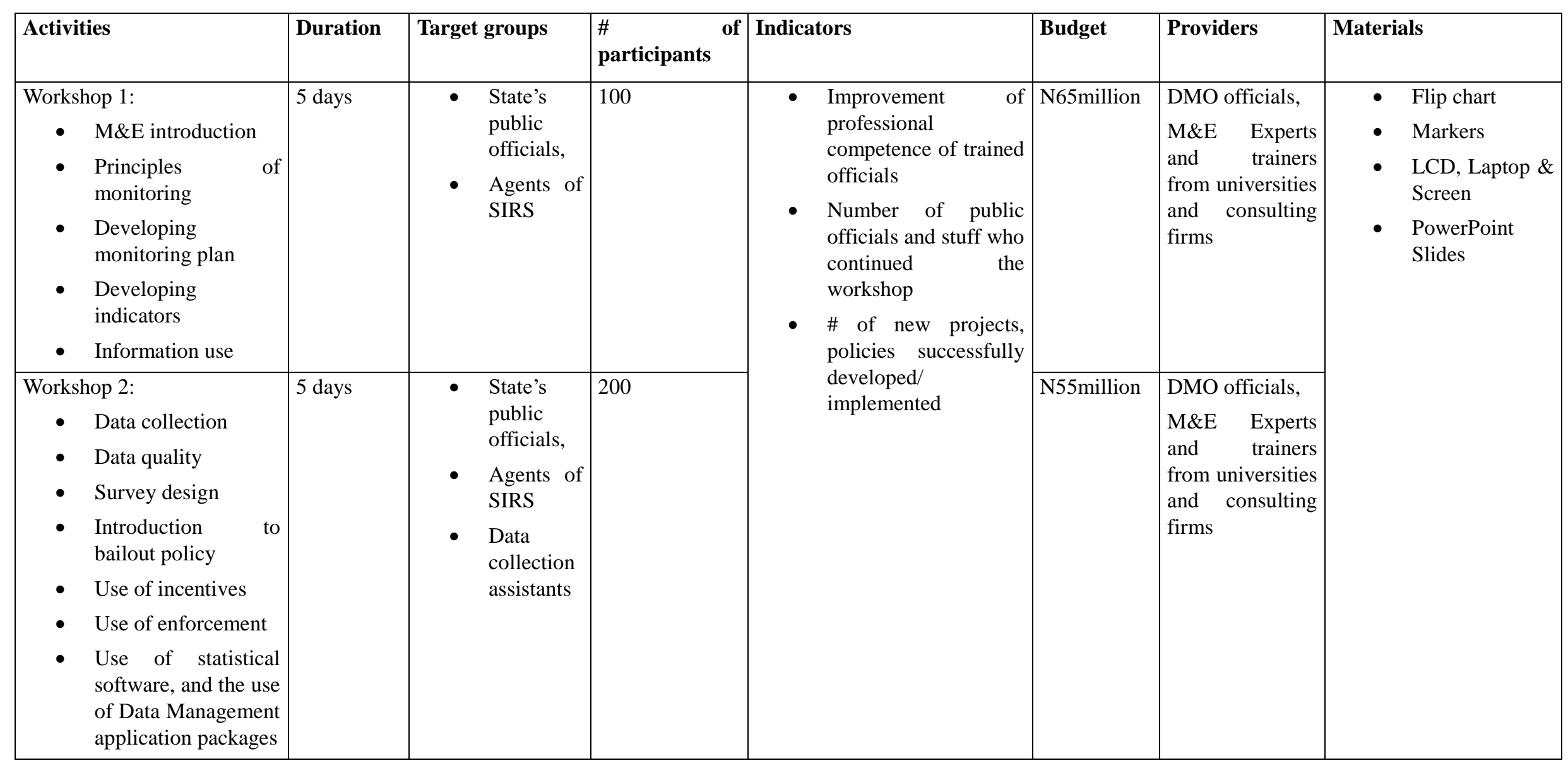

Source: Author's compilation 


\section{Logistical Issues}

Time Schedule for Summative evaluation

Figure 5: Types of evaluation timings

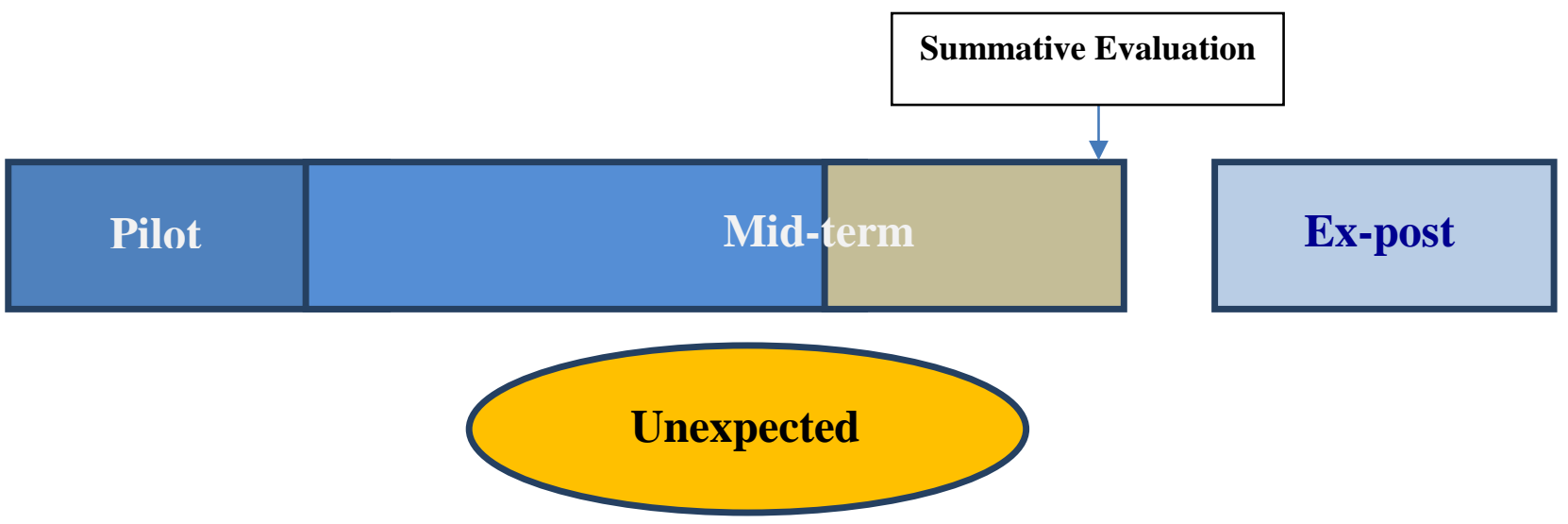

Source: Author's compilation

Due to the emergency of the fiscal intervention activities, the evaluation plan will not conduct a pilot study. Therefore, an ex-ante evaluation will not be conducted. Also, since the time line of the program is in three years, the methodology for evaluating the causal effect of the policy will not be applicable for mid-term evaluations. Hence, the evaluation study will use only the summative evaluation. 
Table 4: M\&E activity time-table (4-years)

\begin{tabular}{|c|c|c|c|c|c|c|c|c|c|c|c|c|c|}
\hline \multirow{2}{*}{ Task } & \multirow{2}{*}{$\begin{array}{l}\text { Yr.0 } \\
\text { Qre.4 }\end{array}$} & \multicolumn{4}{|l|}{ Yr. 1} & \multicolumn{4}{|l|}{ Yr. 2} & \multicolumn{4}{|l|}{ Yr. 3} \\
\hline & & Qtr. 1 & Qtr. 2 & Qtr. 3 & Qtr. 4 & Qtr. 1 & Qtr. 2 & Qtr. 3 & Qtr. 4 & Qtr. 1 & Qtr. 2 & Qtr. 3 & Qtr. 4 \\
\hline \multicolumn{14}{|l|}{ Monitoring } \\
\hline $\begin{array}{l}\text { - Review objectives of } \\
\text { the policy }\end{array}$ & & & & & & & & & & & & & \\
\hline $\begin{array}{l}\text { - Review context, risks } \\
\text { and assumptions } \\
\text { related to the policy }\end{array}$ & & & & & & & & & & & & & \\
\hline $\begin{array}{l}\text { - Monitor effects of } \\
\text { policy }\end{array}$ & & & & & & & & & & & & & \\
\hline $\begin{array}{ll}\text { - } & \text { Monitor } \\
\text { performance } & \text { Key } \\
\text { indicators } & \end{array}$ & & & & & & & & & & & & & \\
\hline $\begin{array}{ll}\text { - } & \begin{array}{l}\text { Monitor physical } \\
\text { activities }\end{array}\end{array}$ & & & & & & & & & & & & & \\
\hline $\begin{array}{l}\text { - Conduct monitoring } \\
\text { of financial inputs }\end{array}$ & & & & & & & & & & & & & \\
\hline \multicolumn{14}{|l|}{ Evaluation (Summative) } \\
\hline $\begin{array}{ll}\text { - } & \text { Summative } \\
& \text { Evaluation }\end{array}$ & & & & & & & & & & & & & \\
\hline \multicolumn{14}{|c|}{ Other: Capacity Building and Special Studies } \\
\hline - $\quad$ Special studies & & & & & & & & & & & & & \\
\hline $\begin{array}{l}\text { - DMO: Staff Training } \\
\text { on M\&E }\end{array}$ & & & & & & & & & & & & & \\
\hline $\begin{array}{l}\text { DMO: Staff Training } \\
\text { on report writing }\end{array}$ & & & & & & & & & & & & & \\
\hline
\end{tabular}

Source: Author's compilation 


\begin{tabular}{|c|c|c|c|c|c|c|c|c|}
\hline \multicolumn{9}{|c|}{ Evaluation time schedule } \\
\hline & & Team Members & $\begin{array}{l}\text { Week } \\
1\end{array}$ & $\begin{array}{l}\text { Week } \\
8\end{array}$ & $\begin{array}{l}\text { Week } \\
17\end{array}$ & $\begin{array}{l}\text { Week } \\
25\end{array}$ & $\begin{array}{l}\text { Week } \\
39\end{array}$ & $\begin{array}{l}\text { Week } \\
48\end{array}$ \\
\hline \multicolumn{2}{|c|}{ Finalization of the Evaluation Plan } & Office of the Secretary-General of the DMO & & & & & & \\
\hline \multirow{7}{*}{$\begin{array}{l}\text { Data } \\
\text { Collection }\end{array}$} & Questionnaire design & \multirow[t]{7}{*}{ Administrative Assistants of the DMO } & & & & & & \\
\hline & Determine/Adjust sample size & & & & & & & \\
\hline & Train Data collectors and data entry personnel & & & & & & & \\
\hline & Pretest questionnaire & & & & & & & \\
\hline & Revise questionnaire & & & & & & & \\
\hline & Conduct the baseline data collection & & & & & & & \\
\hline & Data analysis and interpretation & & & & & & & \\
\hline \multicolumn{2}{|c|}{ Analysis \& Interpretation } & $\begin{array}{l}\text { Staffs of Economics and Statistics department of the } \\
\text { DMO and external evaluators/experts }\end{array}$ & & & & & & \\
\hline \multicolumn{2}{|c|}{ Report and Submission to Congress } & Office of the Secretary-General of the DMO & & & & & & \\
\hline
\end{tabular}


Table 5: Cost of Evaluation (Suggested Estimates):

Budget Amount for each component of the Evaluation; 10\% of the yearly budget (N500million) of the Debt Management Office (DMO) will be committed to this evaluation study. This will be allocated as follows:

\begin{tabular}{|l|l|l|}
\hline Component of the Evaluation & Item & $\begin{array}{l}\text { Estimated } \\
\text { Cost }\end{array}$ \\
\hline Data collection \& management & Survey Instruments & N60million \\
\cline { 2 - 3 } & $\begin{array}{l}\text { Administrative Assistance, Motor Vehicles and fuel } \\
\text { for data collection; communication }\end{array}$ & N20million \\
\hline Analysis; Data capturing & & N 50million \\
\hline External evaluators/experts & Chartered Accountants & N 150million \\
\cline { 2 - 4 } & Professional Tax Consultants and Practitioners & N60million \\
\hline $\begin{array}{l}\text { Capacity building of staff / DMO } \\
\text { Staff Training Leaders }\end{array}$ & Internal Training & N65million \\
\cline { 2 - 4 } & External Consultations and Seminars & N55million \\
\hline Reporting & & N10million \\
\hline
\end{tabular}

Source: Author's compilation

There will be no need to dedicate budget for IT devices and infrastructures, because the monitoring \& evaluation and special duties Unit (M\&E and SD) of the debt management office (DMO), will cover the special assignments of the evaluation, and will be responsible for ensuring compliance with established strategies and benchmarks as approved by the Supervisory Board of the DMO. They will also oversee the DMO's collaboration with all the local and external stakeholders. Also, Information Technology \& Information Systems (IT\&IS) Unit will provide the DMO with the requisite office automation facilities and information technology superstructure for the delivery of content by client departments and units involved in the evaluation. 
Journal of Poverty, Investment and Development

ISSN 2422-846X An International Peer-reviewed Journal

Table 6: Proposed Monitoring \& Evaluation Team:

\begin{tabular}{|l|l|l|}
\hline Members & Qualifications & Roles and Responsibilities \\
\hline $\begin{array}{l}\text { Secretary-General of the } \\
\text { DMO (1*Internal) }\end{array}$ & $\begin{array}{l}\text { Ph. D in Economics, with 15 years' experience in public } \\
\text { policy relating to African Economies. }\end{array}$ & Reporting to congress \\
\hline Policy specialists (Internal*5) & $\begin{array}{l}\text { Ph. D degree or at least Master's degree in Economics, } \\
\text { with at least 8 years' experience as head of financial } \\
\text { department in public sector. }\end{array}$ & $\begin{array}{l}\text { Management of methodologies } \\
\text { and technical procedures }\end{array}$ \\
\hline $\begin{array}{l}\text { Policy Coordinators } \\
\text { Internal*10) }\end{array}$ & $\begin{array}{l}\text { Master's degree in Budgeting and Public Finance, with at } \\
\text { least 10 years' experience in monitoring and evaluation of } \\
\text { fiscal policy related projects. }\end{array}$ & $\begin{array}{l}\text { Answer queries about the policy } \\
\text { and its M E Erocedures and } \\
\text { liaise directly with external } \\
\text { stakeholders }\end{array}$ \\
\hline $\begin{array}{l}\text { Data Management } \\
\text { Executives (External } \\
\text { Evaluators*100) }\end{array}$ & $\begin{array}{l}\text { Master's in Statistics and Econometrics, with 5 years' } \\
\text { experience in data management and evaluation }\end{array}$ & $\begin{array}{l}\text { In charge of data analysis and } \\
\text { review of findings and results }\end{array}$ \\
\hline $\begin{array}{l}\text { Data Collection Assistants } \\
\text { (External*150) }\end{array}$ & $\begin{array}{l}\text { College graduates in statistics or IT, with 2 years' } \\
\text { experience in data collection. }\end{array}$ & $\begin{array}{l}\text { Administering questionnaires and } \\
\text { collecting quantitative data }\end{array}$ \\
\hline
\end{tabular}

Source: Author's compilation

\section{Conclusion}

Based on a technically systematic adoption of the World Bank's framework on monitoring and evaluating public policy across the globe, this study intervenes in the discourse on the structure and forms of central government intervention during fiscal crisis of sub-national governments. It highlights in essence that for a bailout or stimulus package to erode incentives for over-dependence, there is need for the central government to establish accurate and logical monitoring framework. This should be met by timely evaluation plans that confirm the ability of the lower level government to utilize funds effectively and efficiently to avert future crisis, as well as provide a blueprint and providential solutions to adverse future shocks in government's sources of revenue.

\section{Acknowledgement}

The authors acknowledge the professional guidance and consultancy of Professor Sung Joon Paik (Ph.D. Economics Harvard University)

\section{References}

Carol H. Weiss (1998). Evaluation (2 ${ }^{\text {nd }}$ edition). Upper Saddle River, NJ.: Prentice Hall.

Debt Management Office, Federal Republic of Nigeria. Available at https://www.dmo.gov.ng

Jody Zall Kusek and Ray C. Rist (2004). Ten Steps to a Results-Based Monitoring and Evaluation System. Washington D.C.: The World Bank.

Keith Mackay (2007). How to Build M\&E Systems to Support Better Government. Washington, D.C.: The World Bank. http://www.worldbank.org/ieg/ecd/docs/How to build_ME_gov.pdf 
Vitae

Adedoyin Festus Fatai is a recipient of the Bournemouth University, $2017 \mathrm{PhD}$ Studentships at the Faculty of Management. He earned a Bachelor's Degree in Economics (Nigeria) and a Masters in Development Policy [South Korea] with concentration on Sustainable Development. Till date, he has continually improved on Mathematical Economics, Research Methods, Quantitative Methods, Econometrics, and Impact Evaluation Methods. Such skills and capabilities are necessary for a Ph.D. degree in Economics, and to engage in joint research with fellow academic. He has authored and co-authored a number of articles in reputable journals.

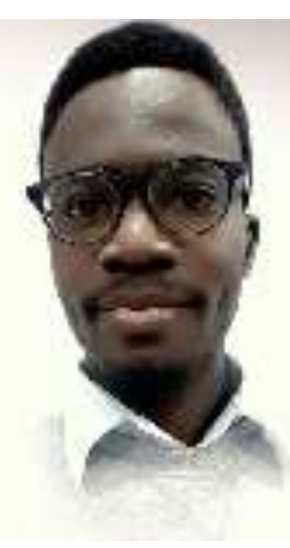

